\title{
ETIKA PENGEMBANGAN DIRI DAN KEMAMPUAN KOMUNIKASI STAF DALAM MEMBERIKAN PELAYANAN PRIMA KEPADA SISWA DI YAYASAN PKBM AMARI MERUYA
}

\author{
${ }^{1}$ Unik Desthiani, ${ }^{2}$ Katry Anggraini, ${ }^{3}$ Nur Rachmah Wahidah, \\ ${ }^{4}$ Nurhayati, ${ }^{5}$ Lisa Novia \\ Dosen Fakultas Ekonomi Universitas Pamulang \\ Email: 1. dosen00031@unpam.ac.id
}

\begin{abstract}
ABSTRAK
Tujuan pada Pengabdian Kepada Masyarakat (PKM) ini adalah untuk mengetahui Etika Pemngembangan Diri dan kemampuan Komunikasi staf dalam memberikan pelayanan warga belajar di yayasan PKBM Amari Meruya. Metode yang dilakukan dalam kegiatan Pengabdian Kepada Masyarakat (PKM) ini pemateri 1 dan pemateri 2 melakukan studi lapangan, dengan mendatangi langsung pada subjek penelitian untuk diberikan pengarahan dan pembelajaran pada staf PKBM Amari Meruya agar dapat melatih dan mencoba untuk memperbaiki kesalahan-kesalahan pada berkomunikasi dan bagaimana beretika yang baik kepada warga belajar. Hasil dapat disimpulkan bahwa Dalam mewujudkan etika yang baik dalam pemberikan pelayanan dipengaruhi dua faktor. Faktor pertama, yaitu faktor manusia yang memberikan pelayanan tersebut. Manusia (staf) yang melayani warga belajar harus memiliki kemampuan melayani siswa secara tepat dan cepat.

Dengan berlaku sopan, ramah, murah senyum, dan berperilaku menyenangkan pada siswa, maka staf PKBM Amari pun akan berlaku sebaliknya. Dengan merasa dihormati dan dihargai siswa, staf PKBM Amari Meruya Selatan harus dapat berlaku lebih dalam memberikan pelayanan terhadap siswa.
\end{abstract}

\section{Kata Kunci: Etika, Komunikasi, Pelayanan Prima}

\section{PENDAHULUAN}

Komunikasi merupakan suatu proses dua arah yang menghasilkan pertukaran informasi dan pengertian antara masing-masing individu yang terlibat. Komunikasi merupakan dasar dari seluruh interaksi antar manusia. Komunikasi merupakan kebutuhan hakiki dalam kehidupan manusia untuk saling tukar menukar informasi, karena tanpa komunikasi-interaksi antar manusia, baik secara perorangan, kelompok maupun organisasi tidak mungkin terjadi. Manusia memerlukan kehidupan sosial, kehidupan bermasyarakat. Sebagian besar interaksi manusia berlangsung dalam situasi komunikasi interpersonal (komunikasi antar pribadi).

Proses komunikasi yang terjadi di dalam perusahaan khususnya yang menyangkut komunikasi antara pimpinan dan bawahan merupakan faktor penting dalam menciptakan suatu organisasi yang efektif. Komunikasi efektif tergantung 
dari hubungan karyawan yang memuaskan yang dibangun berdasarkan iklim dan kepercayaan atau suasana organisasi yang positif. Hubungan atasan dan bawahan merupakan jantung pengelolaan yang efektif. Agar hubungan ini berhasil, harus ada kepercayaan dan keterbukaan antara atasan dan bawahan. (Muhammad, 2001: 172).

Rasa percaya, keyakinan, keterbukaan, kejujuran, dukungan keamanan, kepuasan, keterlibatan, tingginya harapan merupakan gambaran iklim perusahaan yang ideal. Tujuan utama dari komunikasi antara atasan dengan bawahan adalah mengidentifikasi, menciptakan dan menjalin hubungan timbal balik yang menguntungkan antara pimpinan dengan bawahan.

Komunikasi yang efektif ditentukan oleh pihak-pihak yang terlibat di dalamnya, yaitu pimpinan dan karyawan. Pimpinan harus dapat memfasilitasi kondisi komunikasi antar pribadi yang efektif . Komunikasi antar pribadi yang efektif meliputi: keterbukaan (openness), empati (empathy), kepositifan (positiveness), dukungan (supportiveness), kesetaraan (equality). Yayasan PKBM amani adalah yayasan Permasalahan yang timbul dalam Yayasan PKBM Amani adalah sebagai berikut: Kebijakan yang tidak tetap (konsisten) sering kali menimbulkan kesalah fahaman antara siswa dengan staf yayasan, Kurangnya kemampuan Staf dalam berkomunikasi sehingga koordinasi antar staff baik atasan ataupun bawahan tidak maksimal, Komunikasi yang dilakukan secara verbal dan nonverbal yang diberikan staf tidak sesuai dengan SOP, Kurangnya Keterampilan komunikasi yang dimiliki oleh Staf sehingga belum mampu beradaptasi dengan lawan bicara yang memiliki latar belakang yang berbeda agar komunikasi yang dilakukan dapat berjalan efektif, maka dibutuhkan suatu komunikasi yang berlaku pada setiap pihak-pihak yang terkait di dalamnya. Komunikasi yang berlaku dalam organisasi erat kaitannya dengan tujuan dan pencapaian target organisasi. Dalam pelaksanaannya, komunikasi dalam perusahaan senantiasa terjadi baik itu antara bawahan dengan bawahan, bawahan dengan atasan, maupun staff dengan manager dan dengan pihak yang terkait lainnya.

Dalam rangka menjalankan dan menyelengggarakan aktivitas serta kegiatan pendidikan bagi masyarakat, PKBM Amari perlu memberikan kenyamanan kepada para warga belajar, rasa nyaman tersebut bisa tercipta dengan adanya pelayanan prima dari setiap bagian yang ada di PKBM Amari mulai dari staf, pengajar sampai dengan pimpinan PKBM Amari itu sendiri.

Banyak terdapat berbagai kendala yang dihadapi oleh PKBM Amari Meruya antara lain yaitu: terkadang informasi yang diberikan tidak konsisten dari staf sehingga warga belajar maupun orang tua sering terjadi keluhan, kurangnya memiliki keterampilan dalam berkomunikasi yang baik dan efektif sehingga dampak pada etikanya kurang baik, dan terdapat keluhan dari siswa maupun para orang tua karena tidak dapat berkoordinasi dengan baik yang terkadang informasi yang penting telat untuk disampaikan.

\section{METODE PELAKSANAAN KEGIATAN}




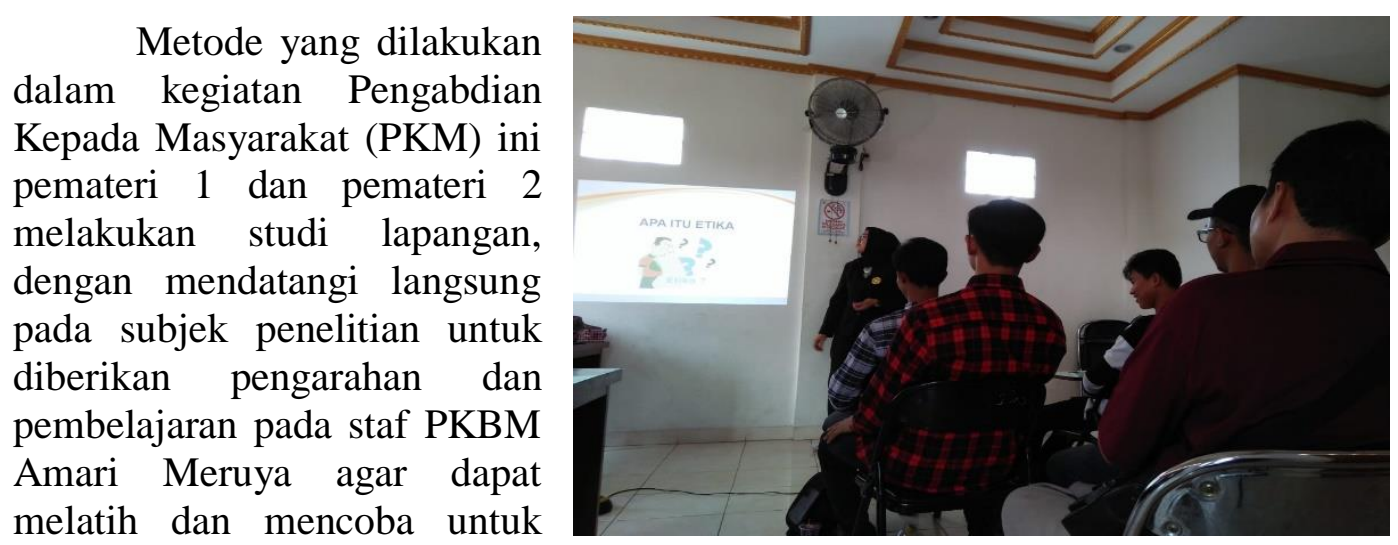

memperbaiki kesalahan-kesalahan pada berkomunikasi dan bagaimana beretika yang baik kepada siswa. Dalam Pengabdian Kepada Masyarakat (PKM) ini dilakukan untuk memperoleh berbagai teori dan asumsi yang berhubungan dengan permasalahan yang diteliti di lapangan berupa literatur-literatur atau bahan bacaan seperti buku, jurnal dan referensi lain berkaitan dengan masalah yang diteliti pada kegiatan Pengabdian Kepada Masyarakat (PKM).

Jenis metode yang digunakan adalah metode kualitatif.

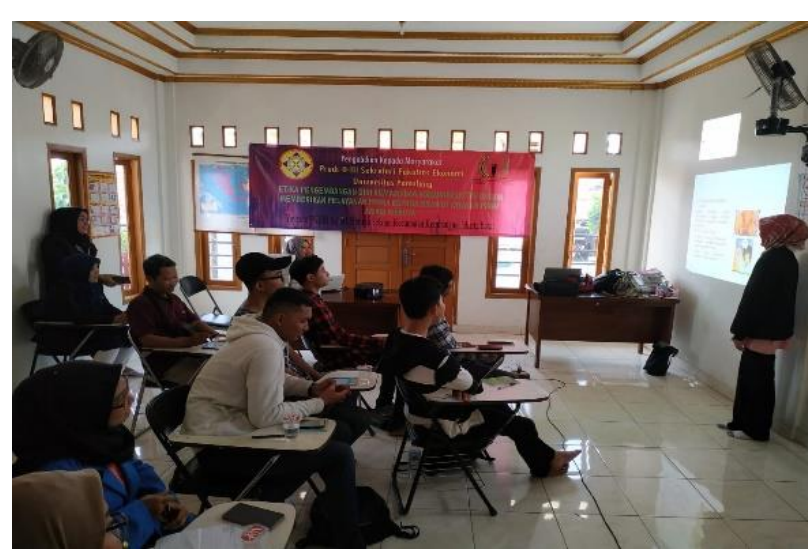

Metode kualitatif adalah sebuah metode riset yang sifatnya deskriptif, menggunakan analisis, mengacu pada data, memanfaatkan teori yang ada sebagai bahan pendukung, serta menghasilkan suatu teori. Subyek dalam Pengabdian Kepada Masyarakat (PKM) ini adalah staf PKBM Amari Meruya dan objek dalam Pengabdian Kepada Masyarakat

(PKM) yaitu PKBM Amari Meruya.

Tahap yang pertama: Dosen yang melakukan Pengabdian Kepada Masyarat (PKM) berkoordinasi dengan mahasiswa dan Ketua Yayasan guna memperoleh perizinan untuk menyelenggarakan Program Pengabdian Keapada Masyarakat (PKM) sebagai salah satu tugas dosen dalam mengamalkan Tri Dharma Perguruan Tinggi.

Tahap yang kedua: Dosen yang melakukan kegiatan Pengabdian Kepada Masyarakat (PKM) memberikan beberapa materi, simulasi, dan berdiskusi sesuai dengan kebutuhan staf PKBM Amari Meruya terkait Etika dan Kemampuan Komunikasi pada siswa PKBM Amari Meruya.

Tahap yang ketiga: Dosen pelaksana Pengabdian Kepada Masyarakat (PKM) melakukan evaluasi terhadap materi yg diberikan oleh pemateri 1 dan 2.

Kegiatan Pengabdian Kepada Masyarakat (PKM) diadakan di Jalan H. Sa'aba RT. 008/03 No.5 Kelurahan Meruya Selatan, Kecamatan Kembangan- 
Jakarta Barat. Waktu untuk pelaksanaannya selama 3 (tiga) hari mulai tanggal 16 sampai dengan 18 November 2019.

\section{HASIL DAN PEMBAHASAN}

Kegiatan Pengabdian kepada Masyarakat ini antara lain : Etika Komunikasi Staf PKBM Amari dalam Memberikan Pelayanan kepada warga belajar. Dalam mewujudkan etika yang baik dalam pemberikan pelayanan dipengaruhi dua faktor. Faktor pertama, yaitu faktor manusia yang memberikan pelayanan tersebut. Manusia (staf) yang melayani warga belajar harus memiliki kemampuan melayani siswa secara tepat dan cepat. Di samping itu, staf harus memiliki kemampuan dalam berkomunikasi, sopan santun, ramah dan bertanggung jawab penuh terhadap warga belajar, serta memiliki pengetahuan dan kemampuan yang baik dalam memahami kebutuhan siswa.

Faktor kedua dalam memberikan pelayanan yang terbaik juga harus diikuti oleh tersedianya sarana dan prasarana yang mendukung kecepatan, ketepatan, dan keakuratan pekerjaan. Sarana dan Prasarana yang dimiliki harus didukung oleh kemajuan teknologi terkini dan teknologi ini juga harus dioperasikan oleh manusia yang berkualitas pula. Tidak kalah pentingnya adalah untuk menghindari pelanggaran terhadap etika pelayanan yang dapat berakibat komplain atau buruknya pelayanan yang diberikan.

Menjalankan etiket pelayanan yang baik tidak hanya akan sangat bermanfaat bagi perusahaan saja, namun juga akan bermanfaat bagi pelanggan yang berhubungan langsung ataupun masyarakat luas. Adapun etiket komunikasi staf PKBM Amari dalam memberikan pelayanan kepada siswa:

1. Percaya Diri

Dengan adanya etiket akan meningkatkan rasa percaya diri kepada staf

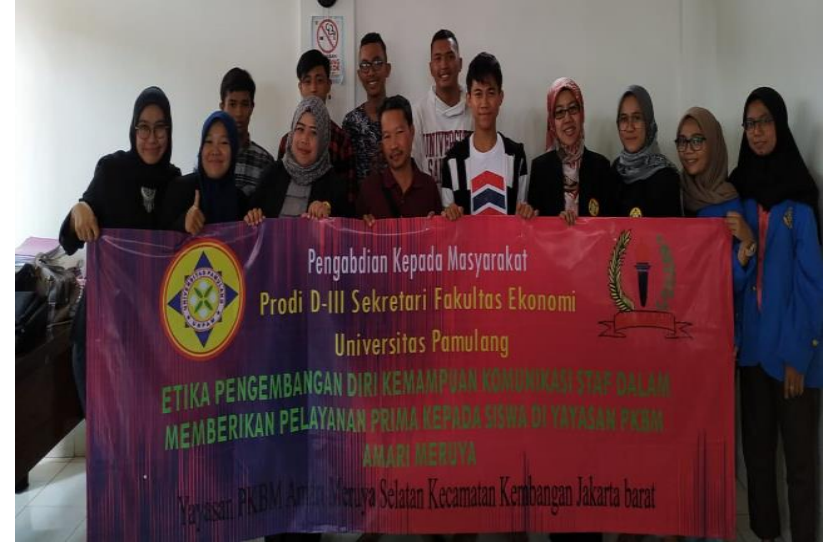

PKBM Amari Meruya Selatan. Percaya diri yang tinggi perlu dan harus dilakukan agar mampu menumbuhkan motivasi staf PKBM Amari Meruya Selatan untuk meningkatkan pelayanan yang sesuai dengan harapan atau tujuan PKBM Amari Meruya.

2. Dihormati dan Dihargai

Dengan berlaku sopan, ramah, murah senyum, dan berperilaku menyenangkan pada warga belajar maka staf PKBM Amari Meruya pun akan berlaku sebaliknya. Dengan merasa dihormati dan dihargai siswa, staf PKBM Amari Meruya harus dapat berlaku lebih dalam memberikan pelayanan terhadap warga belajar. 
3. Disegani dan Disenangi

Dengan etiket yang baik dalam memberikan pelayanan kepada siswa, sering terjadi staf PKBM Amari Meruya akan sangat menjadi disegani dan disenangi oleh warga belajar, sehingga siswa berbuat yang tidak-tidak pada staf PKBM Amari Meruya.

\section{KESIMPULAN DAN SARAN}

Dari pembahasan dan hasil dapat disimpulkan bahwa dalam mewujudkan etika yang baik dalam memberikan pelayanan dipengaruhi dua faktor. Faktor pertama, yaitu faktor manusia yang memberikan pelayanan tersebut. Manusia (staf) yang melayani siswa harus memiliki kemampuan melayani siswa secara tepat dan cepat.

Dengan berlaku sopan, ramah, murah senyum, dan berperilaku menyenangkan pada warga belajar, maka staf PKBM Amari Meruya pun akan berlaku sebaliknya. Dengan merasa dihormati dan dihargai warga belajar, staf PKBM Amari Meruya harus dapat berlaku lebih dalam memberikan pelayanan terhadap siswa.

Disarankan kepada staf PKBM Amari agar selalu memberikan pelayanan yang terbaik bagi siswa.

\section{DAFTAR PUSTAKA}

Adams, dkk. 2007. Etika Profesi. Jakarta: Gramedia.

Agoes, Sukrisno. 2012. Etika Bisnis dan Profesi. Jakarta: Penerbit Salemba Empat.

Anggraini, Katry. Peranan Resepsionis Pada PT Mogems Putri International $\begin{array}{lllll}\text { Jakarta. } & \text { Vol } & 4 & \text { No.2 } & \text { (2017) }\end{array}$ unpam.ac.id/index.php/Sekretaris/issue/view/135

Bertens, K. 2007. Etika. Jakarta: PT Gramedia Pustaka Utama.

Cangara, Hafied. 2006. Pengantar Ilmu Komunikasi. Jakarta: PT. RajaGrafindo Persada.

Djuarsa, sasa. 1994. Teori Komunikasi. Jakarta: Universitas Terbuka.

Effendy, Onong. 2000. Ilmu Teori dan Filsafat Komunikasi. Bandung: PT. Rosdakarya.

Ernawan, Erni R. 2016. Etika Bisnis. Bandung: Penerbit Alfabeta.

Rakhmat, Jalaludin. 2013. Psikologi Komunikasi. Bandung: PT. Remaja Rosda Karya.

Sarah, Nur Aini. Bahasa NonVerbal Dalam Komunikasi. Vol 1, No 2 (2014)

http://openjournal.unpam.ac.id/index.php/Sekretaris/article/view/617 